\title{
Contents to Volume 16 (2020)
}

\author{
Editorial 1
}

\author{
HEALTH, WELL-BEING, AND OLD AGE IN EARLY CHRISTIANITY
}

An Economic Analysis of the Perception of 'Grief' in the Letter to Philippians in the Light of New Institutional Economics (NIE) 3 Professor Alex Hon Ho Ip

Patristics and Sociolinguistics 20 Cyril Hovorun

Does Human Soul Have an Owner? 30 Basil Lourié

Some Aspects of Monastic Diets from Thebes 48 Hind Salah El-Din Somida Awad

Re-examining Ambrose's Ep. 24. The Exceptional Case of the Bishop's Hearing 58 Hiroshi Tone

Pelagius' View of Ideal Christian Women in his Letters 67 Nozomu Yamada

\section{LITURGY AS PRACTICE, SPACE, AND THEORY IN EASTERN CHRISTIANITY}

The Reform of the Hirmologion by the Russian Old Ritualists 89 Aleksandr Andreev

Petr Sevast'anov and his expeditions to Mount Athos (1850s): two cartons from the French Photographic Society 105

Lora Gerd

The Liturgical Service of the Hegumen According to the Canons of the Constantinople Council of $1276 \quad 124$ Maria Korogodina 
Depicting a Prayer before the Battle: On the Reader's Marginalia Drawing in the Old Rus' Manuscript from the British Library 135

Fedor Veselov

\section{ARTICLES}

The Syncretic Revelation of John of Gaza 147

Tatiana Aleksandrova

The Arabic Book of the Divine Liturgies Printed in 1745 in Iași by Patriarch Sylvester of Antioch $\quad 158$

Ioana Feodorov

Naming God: Exodus 3:14-15 in Augustine's Enarrationes in Psalmos 177

Michael Glowasky

Pseudo-Athanasian Homily on the Man Born Blind: Slavonic Sermon from an Unknown Greek Original 188

Irina M. Gritsevskaya and Viacheslav V. Lytvynenko

Traits of positive and negative discrimination of the Copts in medieval Egypt as described by the "History of the Patriarchs of Alexandria" 214

Anastasia M. Ivanova

A Conceptualist Turn: The Ontological Status of Created Species in Late Greek Patristic Theology 233

Dirk Krausmuller

Personal Eschatology in the Old Believer Polemical Writings between 17th and 2oth Centuries 253

Alexander V.Pigin

Strategies for Quoting the Holy Scriptures in the Old Polish BiblicalApocryphal Narrations 271

Dorota Rojszczak-Robińska

The Origin and Characteristics of the Image of the Aerial Spirits 292

Eugenia Smagina

The Beginnings of the Graeco-Syro-Arabic Melkite Translation Movement in Antioch 306

Alexander Treiger 


\section{REVIEW ARTICLES}

The New Critical Edition of the Martyrdom of the Fifteen Martyrs of Tiberioupolis (B H G 1199) by Irini-Sophia Kiapidou and Several Problems of the Text

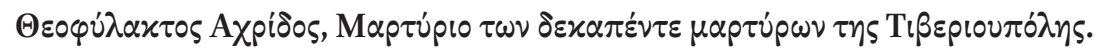

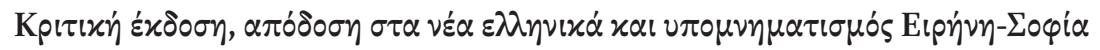

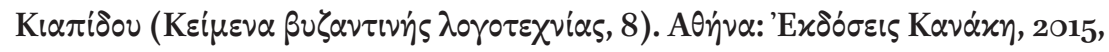
$\sigma \sigma .275333$

\section{Basil Lourié}

Eustratius of Nicaea, a Theologian: About the Recent Publications of Alexei Barmin 344 Basil Lourié

A New Source of the Slavic Menaia 359 Tatiana Pentkovskaya, Translated by Inna N. Fomina

\section{NOTES}

The First Step to Apostasy? (An Ethiopian Ruler's Missive to the Sultan Baybars Re-interpreted) $\quad 367$

Serge A. Frantsouzoff

Swimming against the Tide: How the Monks of Medikion Challenged Traditional Notions of Sainthood 375

Dirk Krausmüller

What Kind of Poetry Would a Syriac Manuscript-Thief Read about Oneself? 390

Anton Pritula

\section{BOOK REVIEWS}

Philip Michael Forness, Preaching Christology in the Roman Near East. A Study of Jacob of Serugh, The Oxford Early Christian Studies, Oxford: Oxford University Press, 2018, XVI+322 p., ISBN 978-o-19-882645-3 399 Dmitry Fedorovich Bumazhnov

Inbar Graiver, Asceticism of the Mind: Forms of Attention and Self-Transformation in Late Antique Monasticism (Studies and Texts, 113), Toronto: Pontifical Institute of Mediaeval Studies, 2018, pp. x, 237. 405 Basil Lourié 
Платонов Вячеслав Михайлович, Рукописная книга в традиционной культуре Эфиопии, Санкт-Петербург: Российская Национальная Библиотека, Российская Академия Наук, Институт Восточных Рукописей, 2017, 216 стр. 410

Platonov Vyačeslav Michajlovič. The Manuscript Book in the Traditional Culture of Ethiopia, Saint Petersburg: Russian National Library, National Academy of Science, Institute of Oriental Studies, 2017, 216 pp. 410 Nafisa Valieva 